
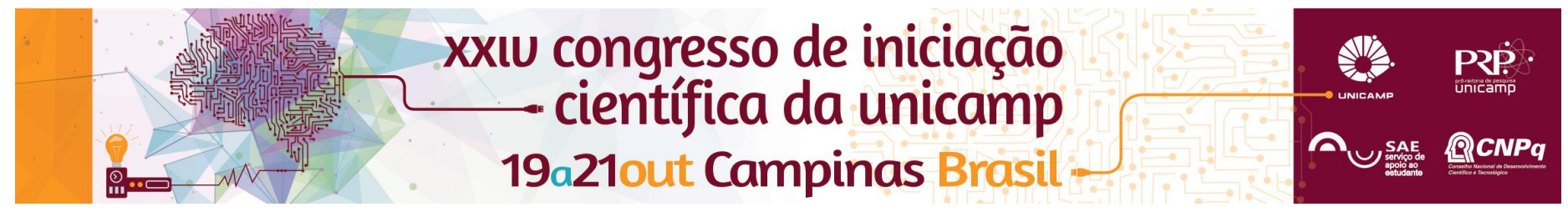

\title{
Análise e discussão da aplicabilidade da teoria de jogos esportivos de Júlio Garganta para o Futebol Americano
}

\section{Renan Schroter*, Sérgio Settani Giglio}

\section{Resumo}

O presente trabalho analisou a possibilidade do uso da teoria de jogos esportivos de Júlio Garganta (1995) para o futebol americano. Por meio de revisão bibliográfica o trabalho procurou debater essa teoria face os métodos já utilizados por treinadores da modalidade, assim como as dificuldades da aplicação da mesma por conta das especificidades do esporte. Esse trabalho também procurou possibilitar o início de debates e produções sobre as metodologias de ensino do futebol americano, já que são poucas as produções acadêmicas sobre o esporte.

Palavras-chave:

Futebol Americano, Júlio Garganta, pedagogia.

\section{Introdução}

O futebol americano, modalidade esportiva com grande crescimento no Brasil, é um esporte de invasão e disputa direta pela bola, conforme os conceitos de Bayer (1994). Como sua prática se difundiu apenas recentemente no país, poucas foram as produções acadêmicas sobre a modalidade, em especial sobre os métodos e pedagogias de ensino. Esse trabalho discute sobre as possibilidades de aplicação da teoria de jogos esportivos de Júlio Garganta para o futebol americano, assim como as dificuldades dessa aplicação, bem como a possibilidade de estruturar gerar uma base para futuros trabalhos que discutam o assunto.

\section{Resultados e Discussão}

Ao se analisar os conceitos de lógica interna e princípios operacionais de Bayer (1994), temos que o futebol americano se encaixa em todos os itens, podendo assim ser tratado em toda sua extensão como Jogo Desportivo Coletivo, sendo esse ponto importante para viabilizar a análise do esporte sob a luz das teorias de Júlio Garganta (1995), que em muito se fundamentam nos conceitos de Bayer (1994).

Garganta (1995) propõe principalmente a utilização de jogos adaptados, com número reduzidos de jogadores, em espaços menores e regras simplificadas, como meio de ensino do jogo, sendo que assim ocorreria uma maior continuidade das ações e uma maior possibilidade de concretização. Analogamente existem já modalidades como o flag football e touch que possuem essas características, e muitas vezes são praticados por jovens antes de começarem a praticar a principal modalidade do futebol americano, o full pad, em grande parte por estas terem contato físico reduzido ou quase nulo, tornando o jogo mais seguro.

Diversos treinadores americanos, como Robert Ash (2006), trazem conceitos e ideias mais próximos do método sintético-analítico, no qual ele dividem os movimentos e técnicas, ensinando-as parte a parte, para então juntar essas partes e formar a técnica como um todo. Mas há o exemplo de Glenn "Tiger" Ellison, técnico que, de acordo com Chris Brown (2012), criou um sistema baseado na observação de crianças jogando em um parque, sistema esse que permite uma maior autonomia dos jogadores, criando situações mais imprevisíveis, concomitante com a ideia de Garganta (2006), de que o jogo é composto de duas dimensões, sendo uma previsível e outra imprevisível, sendo que o conjunto delas geram acontecimentos diversos e singulares.

Em vista de como se dá a prática do futebol americano no Brasil, com grupos heterogêneos e experiências e vivências nesse e em outros esportes muito diversa, o uso do conceito de fases do jogo de Garganta (1995) pode ser muito útil, uma vez que com esse conceito pode-se pensar em que fases os jogadores se encontram e como deve ser trabalhado cada um deles. Unindo-se esse conceito ao dos níveis de relação (GARGANTA, 1995), pode-se ter uma variedade de ferramentas que auxiliem o ensino do futebol americano.

\section{Conclusão}

As teorias e propostas metodológicas de Júlio Garganta (1995), podem não só serem aplicadas ao futebol americano, como podem ser utilizadas como ferramentas para ensinar grupos heterogêneos.

No entanto, ainda restam pontos a serem discutidos de como seria esse ensino quanto a, por exemplo, o contato físico intenso do jogo.

\section{Agradecimentos}

Agradeço a UNICAMP, ao prof. Sérgio Giglio, pelo apoio e orientação, e a todos que me auxiliaram para que esse projeto se tornasse real. Agradeço ao SAE pela bolsa de pesquisa.

ASH, R. Coaching Football: Technical nad Tactical Skills. Human Kinetics, 2006 .

BAYER, C. O ensino dos deportos colectivos. Lisboa, Dinalivro, 1994. BROWN, C. The Essential Smart Football. Createspace, 2012. GARGANTA, J. (Re)fundar os conceitos de estratégia e tática nos jogos desportivos colectivos, para promover uma eficácia superior. Revista Brasileira de Educação Física, São Paulo, 2006.

GARGANTA, J. Para uma teoria dos jogos desportivos coletivos. O ensino dos jogos desportivos. 2ed. Porto: Universidade do Porto, 1995. 